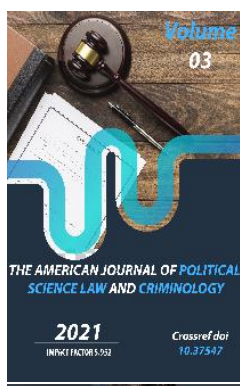

\title{
Problems Of Legal Regulation Of Recognition And Enforcement Of International Arbitral Awards In Uzbekistan
}

\author{
Sherali Subkhonov \\ Master Student, Department Of "Business Law" Tashkent State University Of Law, Uzbekistan
}

Journal Website: http://usajournalshub.c om/index,php/tajpslc

Copyright: Original content from this work may be used under the terms of the creative commons attributes 4.0 licence.

\section{ABSTRACT}

This article discusses the problems of legal regulation of recognition and enforcement of foreign arbitral awards in Uzbekistan, as well as issues regarding the general procedure for the recognition and enforcement of international commercial arbitral awards, the extend of dissemination of information and the availability and collection of a database on this category of cases, the need for clarification of " Public Order", a review of the current national legislation was carried out. Studied the positive experience of countries with developed legislation regarding the above problems in the recognition and enforcement of foreign arbitral awards. On the basis of the analysis, proposals and recommendations for improving the current legislation are given.

\section{KEYWORDS}

The recognition and enforcement of international commercial arbitral awards, the availability of a database and collection of information on these categories of cases, public order.

\section{INTRODUCTION}

It should be noted that in accordance with the Strategy of Action on the five priority areas of Development of the Republic of Uzbekistan in
2017-2021, the democratization of the judicial and legal system, ensuring its true independence and strengthening guarantees 
of reliable protection of the rights, freedoms and legitimate interests of citizens is one of the important areas of reforms being implemented in Uzbekistan.

In the light of this, one of the most important areas of international legal cooperation and legal assistance is the recognition and enforcement of international commercial arbitral awards on the territory of the Republic of Uzbekistan. This issue is directly related to the developpment of the judicial and legal system and is an indicator of the implementation of international standards in the field of the rule of law.

The lack of a single legislative act regulating the process of recognition and enforcement of international commercial arbitral awards, a single methodology for considering such disputes in economic and civil courts, especially when challenging such awards, leads to misunderstandings on the part of law enforcement bodies and different application of certain rules governing the procedure for recognition and enforcement of international commercial arbitral awards, which requires scientific study of this institute, taking into account foreign experience.

When considering cases on the recognition and enforcement of a international commercial arbitral awards, the courts of the Republic of Uzbekistan apply the following international treaties of the Republic of Uzbekistan:

The Convention on the Recognition and Enforcement of Foreign Arbitral Awards (New

\footnotetext{
${ }^{1}$ https://uncitral.un.org/sites/uncitral.un.org/files/m edia-documents/uncitral/ru/new-york-conventionr.pdf

${ }^{2}$ http://icsidfiles.worldbank.org/ICSID/ICSID/StaticFil es/basicdoc/partA.htm
}

York Convention) regulates the recognition and enforcement of arbitral awards made in the territory of a State other than the State where recognition and enforcement of such awards is sought, disputes on which both natural and legal persons may be parties. It also applies to arbitral awards that are not considered to be domestic awards in the State where their recognition and enforcement is sought ${ }^{1}$.

The Convention" On the Settlement of Investment Disputes between States and Foreign Persons " (Washington Convention) regulates the settlement of investment disputes between participating States and investors. The Washington Convention imposes an obligation on States parties to consider decisions rendered by the arbitration of the International Center for the Settlement of Investment Disputes (ICSID) as binding, recognizing the legal force of decisions rendered by the courts of this State ${ }^{2}$.

\section{THE MAIN FINDINGS AND RESULTS}

The Agreement "On Settling Disputes Related to Commercial Activities " (Kiev Agreement) regulates the resolution of cases arising from contractual and other civil law relations between economic entities, from their relations with state and other bodies, as well as the execution of decisions on them ${ }^{3}$.

The Convention Legal Assistance and Legal Relations in Civil, Family and Criminal Matters (Minsk Convention) regulates the provision of

\footnotetext{
${ }^{3}$ http://www.cisarbitration.com/2017/02/03/kievconvention-on-settling-disputes-related-tocommercial-activities/
} 
legal assistance and legal relations in civil, family and criminal matters, including the recognition and enforcement of decisions made in the territory of other Parties to the Convention ${ }^{4}$.

In addition, when considering cases on the recognition and enforcement of decisions of international commercial arbitrations, the courts of the Republic of Uzbekistan apply the norms and provisions of the economic ${ }^{5}$ and civil Procedure Codes $^{6}$ of the Republic of Uzbekistan, the Law of the Republic of Uzbekistan "On the Execution of Judicial Acts and Acts of other bodies"7 and other normative legal acts

The current legal regimes for the recognition and enforcement of international commercial arbitration awards vary depending on the type of award and the content of the international treaty. At the same time, the legislation does not answer the question of how the decision of the international commercial arbitration on recognition will be enforced, for example, if it requires registration in special registers on the territory of the Republic of Uzbekistan.

In general, in world practice, there are three main ways to recognize and enforce an international commercial arbitration award:

1) When a procedure for the recognition of this awards is necessary, i.e. the so-called

\footnotetext{
${ }^{4}$ http://www.cisarbitration.com/2017/02/03/minskconvention-on-legal-assistance-and-legal-relationsin-civil-family-and-criminal-matters/

${ }^{5}$ https://lex.uz/docs/3523895

${ }^{6}$ https://www.lex.uz/docs/3517334

${ }^{7}$ https://lex.uz/docs/13896

${ }^{8}$ https://cyberleninka.ru/article/n/ispolnenieinostrannyh-sudebnyh-resheniy
}

"issuance of an exequatur"8 (for example, in France, Belgium);

2) When it is sufficient to verify the correctness of the decision only from a formal point of view, as well as not contradicting its public policy in the country of the court (for example, in Italy) 9.

3) When foreign court decisions require registration of the decision in a special register (in the UK) ${ }^{10}$

One of the key problems is the lack of detailed information on the procedure for the recognition and enforcement of international commercial arbitration awards in a simplified and understandable form. This procedure is provided exclusively in the procedural legislation and international treaties of the Republic of Uzbekistan. National legislation is only provided in Russian and Uzbek, without translation into English.

Also, the information systems implemented in civil courts, which allow applicants to submit applications to the courts in electronic form, do not contain such a type of appeal as "An application for recognition and enforcement of an international commercial arbitration award". A similar system implemented in economic courts, although it contains this type of appeal, refers it to the claim proceedings, which is misleading about the procedure and timing of consideration of such applications.

\footnotetext{
${ }^{9}$ Манцевич Т. Признание и исполнение иностранных судебных и арбитражных решений // Бюллетень нормативно-правовой информации. - 2002. - № 30. С. 22

10 Габриэл С., Дамбургс Н. Признание и приведение в исполнение решений российских судов на территории Англии и Уэльса.

file://C:/Users/Rano's\%20Netbook/Downloads/14042041 28.pdf
} 
In addition, the existing differences in the economic and civil procedure codes of the Republic of Uzbekistan do not contribute to the formation of uniform judicial practice. Among such differences, we can note different courts considering applications for recognition and enforcement of an international commercial arbitration award (in economic courts, such applications are considered by second-tier courts, and in civil courts-by firsttier courts), different terms of consideration of such applications (in economic courts, such applications are considered within six months, and in civil courts - within one month from the date of receipt of the application for recognition and enforcement of an international commercial arbitration award).

Significant differences that cause difficulties include the grounds for refusal to recognize and enforce the decision of international commercial arbitration, given in the economic and civil procedure codes of the Republic of Uzbekistan.

If article 370 of the Civil Procedure Code of the Republic of Uzbekistan combines in one article the grounds for refusal as " decisions of a foreign court or a foreign arbitration court (arbitration)", the Economic Procedure Code contains two articles providing for the grounds for refusal to recognize and enforce a decision of a foreign court (Article 255) and a decision of a foreign arbitration (Article 256). It should be noted that international treaties of the Republic of Uzbekistan contain various grounds for refusing to recognize and enforce decisions of foreign arbitration courts (provided for in the Minsk Convention) and decisions of foreign arbitrations (provided for in the New York Convention).
As noted above, the information systems of civil courts that allow filing applications to the courts in electronic form do not contain such a type of appeal as "An application for recognition and enforcement of a decision of a foreign court or arbitration", and a similar system implemented in economic courts, although it contains this type of appeal, refers it to the claim proceedings.

As a result, the bank of court decisions on civil cases posted on the website of the Supreme Court does not allow to create a list of cases of this category for studying judicial practice. And as a result of the incorrect classification of this type of appeals, the bank of decisions of economic courts forms a list of cases in which the decisions based on the results of consideration of applications for recognition and enforcement of an international commercial arbitration award are incorrectly indicated as decisions or a ruling on termination of the case.

Taking into account that such information systems are aimed, among other things, at collecting complete and reliable information about the courts for the consideration of applications, the absence of such a category of applications or the incorrect classification of such a category of applications leads to incomplete collection of information about the activities of courts for the consideration of applications for recognition and enforcement of an international commercial arbitration award. This circumstance leads to the need for manual collection and analysis of information on these types of cases, which can lead to a decrease in the objectivity and reliability of data on the activities of the courts. As a result, there is no way to determine the state of the rule of law in Uzbekistan. 
In addition, the allocation of a separate category of applications for recognition and enforcement of an international commercial arbitration award, as well as an indication of the list of necessary information to be specified in the application and appendices to be attached to the application, will simplify the submission of such applications to the courts.

Article 5 of the New York Convention lists the grounds for refusing to recognize and enforce an award, including if the recognition and enforcement of that award is contrary to the public policy of that country. But the norms of the current legislation do not give a clear definition of public order, and the criteria for which the decision is considered contrary to it.

It should be noted that the number of denials of recognition and enforcement is currently at a low level. Moreover, there is no information that the courts refused recognition and enforcement on this basis.

However, the absence of a clear concept of "public order" in the norms of the current legislation and the criteria for determining contradictions to public order may further lead to different interpretations of the norms in judicial practice.

Insufficient awareness of the procedure for the recognition and enforcement of international arbitral awards in Uzbekistan requires the following measures:

- Wide dissemination of information both on the territory of the Republic of Uzbekistan and at the international level;

- Inclusion of the necessary information in international databases and published publications with relevant topics;
- Conducting training sessions for relevant judicial and law enforcement officials to ensure uniform enforcement;

- Introduction of the possibility of a fullfledged electronic (online) appeal to the courts with applications for recognition and enforcement of decisions of international arbitrations, including the introduction of functions to support foreign languages in the information systems of courts.

\section{CONCLUSION}

Further, the formation of a unified mechanism of law enforcement by civil and economic courts, taking into account international agreements of the Republic of Uzbekistan, the specifics of recognition and enforcement of decisions of state courts of the CIS countries, other foreign countries, as well as international arbitrations.

Further, the legislative consolidation of the concept of "public order" and other grounds for challenging the decision of international commercial arbitration.

Further, the lack of a single database on cases on the recognition and enforcement of international arbitration awards shows the need to create a single electronic system and database on such categories of cases as a separate category and to analyze the implementation of the country's international obligations under concluded bilateral and multilateral international treaties.

Further, the lack of a single database on cases on the recognition an enforcement of international arbitration awards shows the need to create a single electronic system and 
database on such categories of cases as a separate category and to analyze the implementation of the country's international obligations under concluded bilateral and multilateral international treaties.

\section{REFERENCES}

1. The Convention on the Recognition and Enforcement of Foreign Arbitral Awards (New York Convention) //URL: https://uncitral.un.org/sites/uncitral.un.or g/files/media-documents/uncitral/ru/newyork-convention-r.pdf

2. The Convention" On the Settlement of Investment Disputes between States and Foreign Persons " (Washington Convention) //URL: http://icsidfiles.worldbank.org/ICSID/ICSI D/StaticFiles/basicdoc/partA.htm

3. The Agreement "On Settling Disputes Related to Commercial Activities " (Kiev Agreement) //URL: http://www.cisarbitration.com/2017/02/03 /kiev-convention-on-settling-disputesrelated-to-commercial-activities/

4. The Convention Legal Assistance and Legal Relations in Civil, Family and Criminal Matters (Minsk Convention) //URL: http://www.cisarbitration.com/2017/02/03 /minsk-convention-on-legal-assistanceand-legal-relations-in-civil-family-andcriminal-matters/

5. Bilateral investment protection and promotion agreements signed by Uzbekistan URL: http://invest.gov.uz/ru/investor/russkijdvustoronnie-dogovora/

6. Economic Procedural Code of the Republic of Uzbekistan //URL: https://lex.uz/docs/3523895
7. Civil Procedural Code of the Republic of Uzbekistan //URL: https://www.lex.uz/docs/3517334

8. Law of the Republic of Uzbekistan "On the Execution of Judicial Acts and Acts of Other Bodies》 I/URL: https://lex.uz/docs/13896

9. Ж.-П. Ансель, М. Абасси Исполнение иностранных судебных решений //URL: https://cyberleninka.ru/article/n/ispolneni e-inostrannyh-sudebnyh-resheniy

10. Манцевич Т. Признание и исполнение иностранных судебных и арбитражных решений // Бюллелтень нормативноправовой информации. - 2002. - № 30. С. 22.

11. Габриэл С., Дамбургс Н. Признание и приведение в исполнение решений российских судов на террилтории Англии и Уэльса.

//URL:

file://C:/Users/Rano's\%20Netbook/Downl oads/1404204128.pdf 